\title{
Mindfulness-Based Cognitive Therapy (MBCT) in improving quality of life: Case study in Chronic Kidney Disease patients with hemodialysis
}

\author{
Rini Junita Bakri Hasanudin, ${ }^{1}$ Ahmad Gimmy Prathama Siswadi, ${ }^{2}$ Nurul Wardhani ${ }^{3}$ \\ ${ }^{1,2,3}$ Faculty of Psychology, Universitas Padjajaran, Bandung - Indonesia
}

\begin{abstract}
Chronic Kidney Disease (CKD) not only affects the physical condition but also impacts on psychological conditions, such as feeling down, embarrassed by appearance, feelings of worthlessness, anxiety, to despair which is the cause of decreased quality of life. In improving the quality of life requires a psychological intervention called Mindfulness-Based Cognitive Therapy (MBCT). This study aims to seek the effects of MBCT interventions on improving the quality of life of patients with Chronic Kidney Disease (CKD) with hemodialysis. Research participants were 3 people. This research was a case study research with a mixed method. Data analysis strategy used was a concurrent embedded strategy that compares quantitative and qualitative data. The result showed that MBCT interventions could improve participant's quality of life. MBCT interventions provide the skills to be aware of clear thoughts, feelings, and events without assessing them so that patients can sort out the things that originate from their thoughts and distinguish them from actual events. This accomplishment of the result can be perceived from the arising of feeling more enjoy life and there is an increase in scores on each aspect of quality of life on the measurement scale used.
\end{abstract}

Keywords: Mindfulness-Based Cognitive Therapy; quality of life; patients with Chronic Kidney Disease with hemodialysis

\begin{abstract}
Abstrak: Gagal Ginjal Kronis (GGK) tidak hanya berdampak pada kondisi fisik namun juga psikologis, seperti merasa terpuruk, malu dengan penampilannya, tidak berharga, cemas, hingga putus asa yang mengakibatkan turunnya kualitas hidup. Untuk meningkatkan kualitas hidup dibutuhkan intervensi psikologis yang disebbut Mindfulness-Based Cognitive Therapy (MBCT). Penelitian ini bertujuan untuk melihat efek pemberian intervensi MBCT terhadap peningkatan kualitas hidup pasien GGK dengan hemodialisis. Partisipan penelitian berjumlah 3 orang. Penelitian ini adalah penelitian studi kasus dengan mixed method. Strategi analisis data yang digunakan adalah concurrent embedded strategy yang mengkomparasikan data kuantitatif dan kualitatif. Hasil penelitian menunjukkan bahwa intervensi MBCT dapat meningkatkan kualitas hidup partisipan. Intervensi MBCT memberikan keterampilan untuk menyadari pikiran, perasaan, dan peristiwa yang sebenarnya tanpa memberikan penilaian di dalamnya, sehingga pasien mampu memilah hal-hal yang bersumber dari pikirannya dan membedakannya dengan kejadian yang sebenarnya. Keberhasilan ini terlihat dari timbulnya perasaan lebih menikmati hidup dan terdapat peningkatan skor pada tiap aspek kualitas hidup pada skala pengukuran yang digunakan.
\end{abstract}

Kata Kunci: kualitas hidup; Mindfulness-Based Cognitive Therapy; pasien Gagal Ginjal Kronis dengan hemodialisis

Corresponding Author: Rini Junita Bakri Hasanudin (e-mail: rinijunitabakri@gmail.com). Faculty of Psychology, Universitas Padjadjaran, Jl. Raya Bandung Sumedang Km 21, Jatinangor, Bandung, Indonesia 45363. 


\section{Introduction}

Chronic Kidney Disease or abbreviated as CKD is a kidney function condition is declining progressively. Jha et al. (2013) suggested that the prevalence of individuals suffering from chronic renal failure in the world reaches $8-16 \%$ of the population. CKD usually starts from a significant decline in kidney function. Prodjosudjadi et al., (2009) stated that the decline in kidney function was measured by monitoring at the glomerular filtration rate (e-LFG), if the glomerular filtration rate decreased to below $60 \mathrm{ml} / \mathrm{min}$ per $1.73 \mathrm{~m} 2$ according to the Cockroft-Gault adjusted for body surface formula area (CG-BSA). CKD usually starts from a significant decrease in kidney function, which increases the amount of creatinine in the body to a level which cannot be tolerated by the body. Several medical intervention options can be given to replace kidney function, including hemodialysis therapy, CAPD (Continuous Ambulatory Peritoneal Dialysis), CRRT (Continuous Renal Replacement Therapy), and kidney transplantation (Segal, Williams, \& Teasdale, 2013).

Data obtained from the Indonesian Renal Registry (2014) has shown that in Indonesia, the most widely used treatment service for chronic kidney failure patients in hemodialysis therapy. The number of CKD patients, especially for active patients in Indonesia, has increased from 2007 to 2014. The increase has almost reached six times compared to the initial number. The increase in CKD patients with hemodialysis in Indonesia in 2007-2014 as described in Figure 1.

Gooz (2012) explained that hemodialysis therapy is the process of fluid transfer and to overcome it through a semi-permeable membrane in the dialysate which is passed through the blood to the artificial kidney. Aisara, Azmi, and Yanni (2018) revealed that hemodialysis is the process of exchanging solutes and waste products of the body where the waste is withdrawn by the mechanism of passive diffusion. It is hoped that this method can release albumin as the kidneys work. In other words, a hemodialysis is a form of kidney replacement therapy, which the hemodialysis machine takes over the function of the kidneys to carry out the process of removing toxic substances resulting from the body's metabolism.

The process of hemodialysis therapy in individuals who have kidney damage must be able to maintain physical condition. Hemodialysis therapy is a therapy that requires a quite long time for treatment. Patient with CKD need 12-15 hours every week or 3-4 hours each time to undergo hemodialysis therapy. This means that

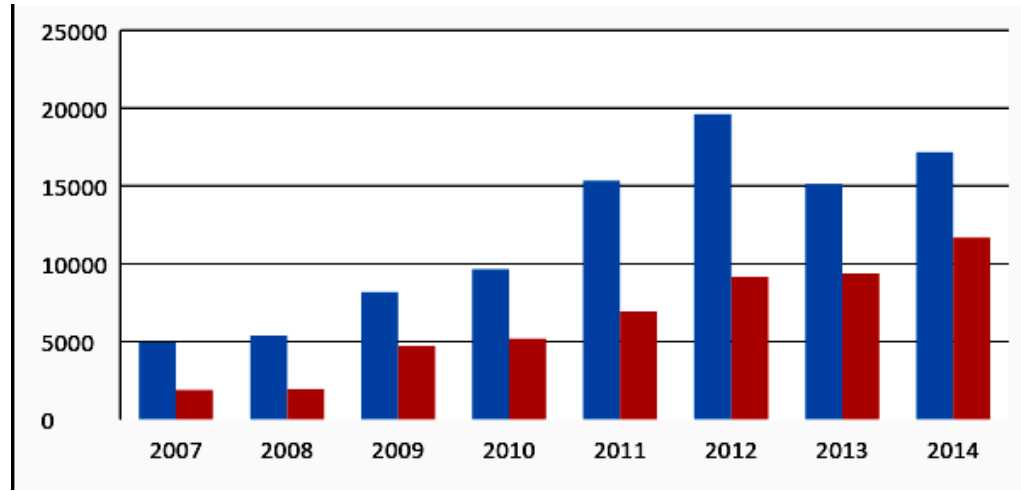

Figure 1. Increase in Chronic Kidney Disease patients with hemodialysis. 
CKD patients with hemodialysis need to spend time reducing their daily activities. With these conditions, Reza (2016) argued that CKD with hemodialysis not only affects the physical condition but also affects the psychological condition of the patient.

Caninsti (2013) stated that CKD can be a stressor in patients, in which patients with chronic kidney disease treat hemodialysis as something that threatens themselves and their families. And this has allowed growing feelings of hopelessness, anxiety, worry about financial problems, feeling a burden to the family, decreased sexual function, and a loss of independence. This does not only occur in patients who have just received a verdict, but these feelings persist even in patients who have long experienced CKD with hemodialysis. Sandra, Dewi, and Dewi (2012) stated that basically, the changes that occur in each CKD patient with hemodialysis are different. This is determined by the patient's ability to adjust. But in general, CKD patients with hemodialysis experience emotional and behavioral changes in the process of adjustment to changes in physical activity, changes in physical function, or things that arise during the process of hemodialysis therapy.

The changes experienced affect the way of viewing the disease and so it makes a decrease in the quality of life in CKD patients with hemodialysis. Hidayah (2016) suggested that the decline in quality of life would include many things, such as disruption of work and activities of daily living. Good quality of life can help CKD patients to undergo hemodialysis with more enthusiasm, and enjoy life more positively and realistically.

Rawat, Joshi, and Arora (2017) suggested that the quality of life in CKD patients with hemodialysis is vastly disturbed especially in patients who begin to experience complications with other diseases. Seidel et al. (2014) argued that CKD patients with hemodialysis experience changes in a negative direction due to many interrelated factors, such as changes in physical strength, changes in daily activities, changes in skin color, changes in sleep patterns, changes in the behavior of people surround and changes in patterns of interacting with others. Rustandi, Tranado, and Pransasti (2018) mentioned that CKD patients with hemodialysis experienced many changes in life that made the quality of life of CRF patients with hemodialysis decreased. The decline in quality of life is illustrated by the dissatisfaction in living everyday life, such as not having a good quality of sleep at night due to decreased physical conditions such as tightness due to excess fluid, patients feel unable to function and unable to serve family members.

Bakri and Usri (2017) proposed a model of quality of life in patients with chronic kidney disease with hemodialysis, as in Figure 2.

Based on Figure 2 it can be shown that the assessment of pain carried out by CKD patients by hemodialysis in which the patient experiences pain and gives a good impression on the physical or feelings of CKD patients, the patient automatically pays special attention to the impressions that arise while making a generally negative assessment of the impression that arises. These negative judgments foster feelings that are usually also negative, such as feeling the treatment is useless or tiring. Negative thoughts and feelings that appear directly proportional to the outlook and assessment of patients for pain that appears. This triggers a perception of decreased quality of life which impacts the disruption of the treatment process or hemodialysis therapy. 


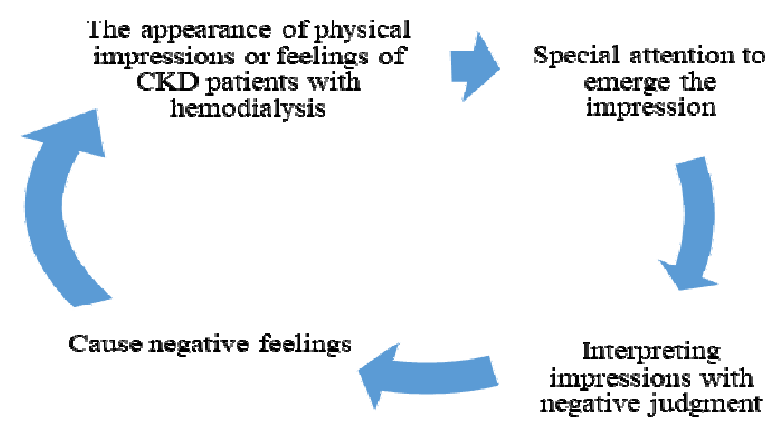

Figure 2. Perception of disease in CKD patients with hemodialysis

The explanation above showed that quality of life is a variable essential on the growth of enthusiasm for treatment in patients with chronic kidney disease with hemodialysis. For this reason, psychological intervention is needed to improve the quality of life of CKD patients. One psychological intervention that is considered capable of controlling judgment and negative feelings in patients with chronic diseases to be more aware of the events they experience is the MindfulnessBased Cognitive Therapy intervention or MBCT.

Based on the literature reviewed, MBCT interventions can improve a person's quality of life by controlling his judgment and negative feelings about life events the person experiences. This is further strengthened by the result of research from Bartley (2012) who researched giving MBCT to cancer patients who are facing the treatment. Bartley (2012) found that MBCT interventions taught different ways to react to adverse conditions, both feelings and thoughts. MBCT can help patients with chronic pain by finding ways to control and manage the pain that is felt. This is possible because in MBCT is learning about how to be aware of events without providing an assessment in the patients, so the patient's reaction or response to the stimulus becomes different.

The similarity of disease characteristics in CKD patients and cancer patients, both from the weakness of physical conditions or psychological conditions that accompany a decrease in physical conditions such as feeling hopeless and the emergence of a feeling of death makes researchers choose samples of CKD patients with hemodialysis. With this background, the researchers propose the hypothesis that there is an effect of providing Mindfulness-Based Cognitive Therapy (MBCT) interventions in improving the quality of life in CKD patients with hemodialysis.

\section{Method}

This research is a case study with a mixedmethod and uses a concurrent embedded strategy to compare the qualitative and quantitative data obtained. The measurement of quality of life variables using the Kidney Disease Quality of Life Scale Form-36 (KDQOL-36) scale compiled by Hays, Kallich, Mapes, Coons, and Carter (1994) which researchers have translated into Indonesian to facilitate research subjects in conducting charging. While the MBCT intervention was carried out as many as 6 meetings. Before testing the hypothesis, the KDQOL-36 scale was tested for reliability and validity using SmartPLS 3 and found the reliability of 0.857 with outer item validity above 0.3 . The research hypothesis test uses thematic analysis to analyze the interview data obtained and compared with scores per aspect on the KDQOL-36 scale given before and after the intervention. 


\section{Participant Characteristics}

The population in this study was CKD patients with hemodialysis at hospital $\mathrm{X}$ in the city of Bandung. Considering a large number of patients and the willingness of patients, thus the researcher cannot take all patients as population. The sample criteria chosen in this study are: 1) Participants are patients with chronic kidney disease with hemodialysis without limitation for long time undergoing hemodialysis treatment, 2) The minimum age of 18 years with the reason 18 years is the lower limit of the adult category, 3) Having the will and being willing to attend all Mindfulness-Based Cognitive Therapy sessions, and 4) Having a low quality of life perception based on the KDQOL-36 scale score distributed in the framework of the KDQOL-36 measurement scale trial.

\section{Research Participants}

The selection of study participants was carried out on the population of the $\mathrm{X}$ hospital in Bandung's renal room by giving the KDQOL-36 scale. Based on the result of the KDQOL-36 scale it was found that $10 \mathrm{CKD}$ patients with hemodialysis at Hospital X had a low quality of life, and 3 of them were willing to be participants in this study. Furthermore, the participants are called P1 (participant 1), P2 (participant 2), and P3 (participant 3).

\section{Pre-intervention in MBCT}

The procedure carried out by the researcher before giving an intervention is: 1) Conduct indepth interviews with each participant to explore the quality of life picture of the study participants. Similar interviews were also conducted with the head of the hospital X hemodialysis unit and the nurse responsible for the patient as supporting data regarding the condition of the study participants. 2) Provides KDQOL-36 scales. 3) Provide an overview of the interventions to be provided.

\section{MBCT Intervention}

Interventions are given individually and have different goals at each meeting. The meeting was held six times and focused on mindfulness techniques then continued with cognitive therapy. MBCT interventions were carried out for 45 - 60 minutes per meeting. In the MBCT intervention, there is an independent exercise task that is recommended to be carried out every day so that research participants can realize their moments, feelings, thoughts, and behaviors that are expected to help participants become more sensitive. Participants are invited to process their reaction to a moment, a thought, feeling, and behavior. Indirectly, this also makes participants able to deal with the uncomfortable feelings they feel.

The MBCT intervention in this study was divided into three stages. The first stage is the exercise to be in a mindful condition (meetings 12 ), the second stage is an exercise to conduct cognitive therapy with the reflection method (meetings 3-4), and the third stage is individual training and monitoring (meetings 5-6). Participants in the research are motivated to be able to deal with the thoughts, feelings, moments, or behaviors that make them less comfortable and then identify the types of reactions they can do to deal with perceived discomfort more effectively.

\section{Post MBCT intervention}

The researchers conducted interviews at the end of each session. After all, sessions ended, the researchers returned the KDQOL-36 scale to show the effect of the intervention on the quality of life of study participants.

\section{Results}

\section{Pre and Post Intervention Results}

Descriptive analysis is obtained from KDQOL36 scores showed improvement in the quality of life before and after MBCT intervention was given. Improved quality of life can be seen in Figure 3. 


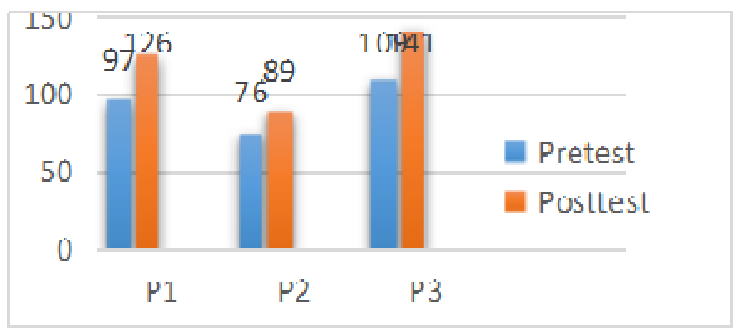

Figure 3. The score of Quality of Life

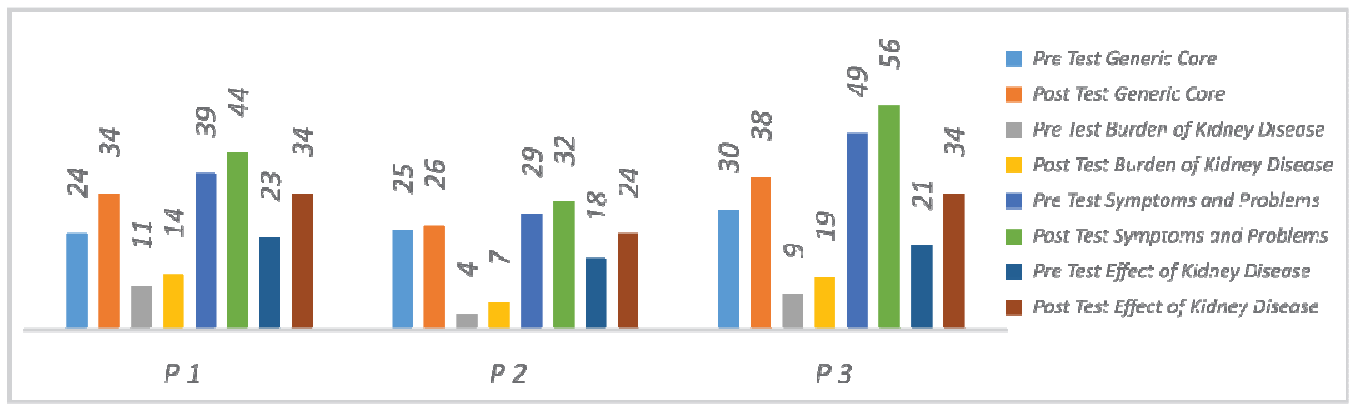

Figure 4. Scores per- Aspect Quality of Life

After giving the MBCT intervention, all study participants showed an increase in scores where two of them were in the high category and one other person was in the moderate category. The increase that occurred in each participant was seen to be quite varied were in P3 the increase reached 32 points, then $\mathrm{P} 1$ the increase reached 29 points, and $\mathrm{P} 2$ the increase reached 13 points. Scores per quality of life aspect can be seen in Figure 4.

When viewed from each aspect, P1 has increased in all aspects of quality of life. Where the increase in aspects of the generic core that occurred by 10 points, aspects of the burden of kidney disease by 3 points, aspects of symptoms and problems by 5 points, and aspects of the effect of kidney disease by 11 points.

In P2 is shown that each aspect, P2 also experienced an increase in all aspects of quality of life. In which the aspects of generic core increase that occurs by 1 point, aspects of the burden of kidney disease by 3 points, aspects of symptoms and problems by 3 points, and aspects of the effect of kidney disease by 6 points.

P3 also experienced an increase in all aspects of quality of life. It is specified in the generic core aspects the increase is 8 points, the burden of kidney disease aspect is 4 points, the symptoms and problems aspect is 7 points, and the effect aspect of kidney disease is 13 points.

In this MBCT intervention, the process of scaling quality of life in CKD patients with hemodialysis is done twice, before the intervention and after the mindfulness-based cognitive therapy intervention. Hence, the result can be shown in Figure 5, it is shown that all three participants experienced an increase in scaling (making a scale) of quality of life after being given an intervention mindfulness-based cognitive therapy. P1 and P2 increased by 2 points, while $P 3$ increased by 6 points. 
P1 (LA), 56 years old, is married and has two children. P1 was sentenced to experience CKD pain by hemodialysis since 2014. Before being convicted of suffering from CKD, P1 was sentenced to hypertension first by a doctor and did oral drug therapy to treat his hypertension. Gradually the hypertension illness suffered by P1 developed into CKD. P1 conducts hemodialysis therapy twice a week with the amount of liquid withdrawal from 3500 to 4000 liters. P1 diligently controls the cardiologist and internist every month. P1 also routinely consumes recommended oral medicines.

P1 (LA) 56 years old, is married and has two children. P1 was determined to have CKD disease by hemodialysis since 2014. Before the determination of suffering from CKD, P1 had been determined by hypertension beforehand by the doctor and did oral drug therapy to manage his hypertension. Gradually the hypertension illness suffered by P1 developed into CKD. P1 conducts hemodialysis therapy twice a week with the amount of liquid withdrawal from 3500 to 4000 liters. P1 diligently controls the cardiologist and internist every month. P1 also routinely consumes recommended oral medicines.
The psychological condition that P1 often complained of during being a CKD patient with hemodialysis is that P1 often feels restless, has trouble sleeping, feels guilty because it is inconvenient for a husband to care for her, and since the treatment, P1 feels that death is so close to her. These feelings are considered disturbing by $\mathrm{P} 1$ and $\mathrm{P} 1$ feels these feelings make the quality of life decline.

The psychological condition that P1 often complained of during being a CKD patient with hemodialysis is that P1 often feels restless, has trouble sleeping, feels guilty because it is inconvenient for a husband to care for her, and since the treatment, P1 feels that death is so close to her. These feelings are considered disturbing by $\mathrm{P} 1$ and $\mathrm{P} 1$ feels these feelings make the quality of life decline.

Despite having been a CKD patient for four years, $\mathrm{P} 1$ is still often overwhelmed with negative feelings and thoughts. P1 has made an effort to reduce or eliminate her negative feelings and thoughts by doing light activities such as walking or walking with her husband using a vehicle, doing light activities such as cooking or studying,

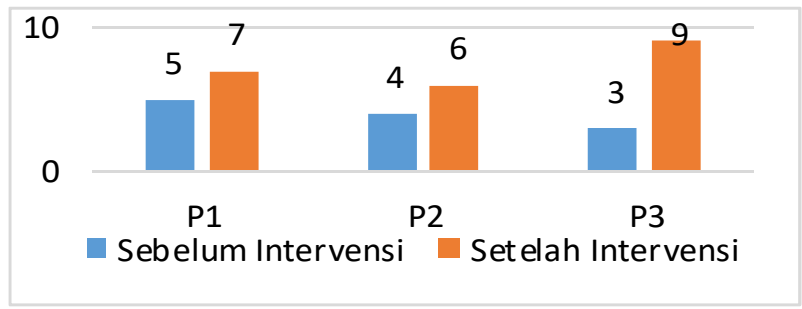

Note:

Before the intervention

After the intervention

Figure 5. Case scheme 
but these negative feelings and negative thoughts only disappear temporarily. When the diversion activities undertaken by P1 were completed, P1 was again overwhelmed with negative feelings and thoughts. This makes the researcher judge that $\mathrm{P} 1$ is suitable for MBCT intervention.

The psychological condition that P1 often complains of during being a CKD patient with hemodialysis is that P1 often feels restless, has trouble sleeping, feels guilty because it is inconvenient for a husband to care for him, and since pain P1 feels that death is so close to him. These feelings are considered disturbing by P1 and P1 feels these feelings make the quality of life decline.

Despite having been a CKD patient for four years, P1 is still often overwhelmed with negative feelings and thoughts. P1 has made an effort to reduce or eliminate her negative feelings and thoughts by carrying out light activities such as walking or walking with her husband using a vehicle, doing light activities such as cooking or recitation, but these negative feelings and thoughts only disappear temporarily. When the diversion activities undertaken by P1 were completed, P1 was again overwhelmed with negative feelings and thoughts. This makes the researcher judge that P1 is suitable for MBCT intervention.

P2 (RM), 20 years old and single. P2 was determined to have CKD disease since 2017. Before the CKD disease was determined by doctors, P2 was a fairly free person with an unhealthy lifestyle. P2 is particularly close to the clubbing world where P2 does not control the amount and intensity of the alcohol to consume, until finally P2 often feels abdominal pain, low back, and feels out of energy. With this complaint, P2 decided to consult a doctor and since then P2 was determined to have CKD. P2 conducts hemodialysis therapy twice a week with the amount of withdrawal of fluids from 3500 - 4000. P2 is diligent in controlling the doctor every month, but almost every week P2 requires additional medical assistance outside of hemodialysis therapy which is done twice a week because P2 has not been able to fully adapt with his current physical condition. Sometimes P2 still consumes alcoholic drinks and heavy activities that are no longer able to be borne physically.

This considerably affects the psychological condition of P2. P2 considers the sickness he suffered a disturbing burden. P2 also complained that his illness made P2 feel alone until he felt lonely, had many thoughts that made him lose enthusiasm, felt unworthy and unfit to be loved, became a burden to his family, felt different from his peers, and had a fear of the dead. These feelings make P2 feel that his quality of life is far different from the situation before he was ill. P2 feels that his quality of life is significantly low.

Researchers perceive that $\mathrm{P} 2$ is suitable to be given an MBCT intervention because $\mathrm{P} 2$ is still in the stage of adaptation to the sickness experienced. So P2 needs to be more sensitive to emotional conditions that can affect his physical condition, and be able to establish more effective responses in those conditions.

P3 (RT), 29 years old and unmarried. He was determined to have CKD with hemodialysis since 2011. Before he was diagnosed with CKD, P3 had been suffering from diabetes mellitus since junior high school. When he was going to college, P3 was diagnosed with suffering from CKD and had to undergo hemodialysis therapy. P3 conducts hemodialysis therapy twice a week with the amount of liquid withdrawal from 3500 - 4000 liters. P3 diligently controls the kidney doctor and ophthalmologist every month. P3 also routinely consumes recommended oral medicines. 
Even so, P3 still felt the pain he suffered had an unfavorable impact on his psychological condition. P3 feels that as long as he is a CKD patient with hemodialysis the appearance changes. P3 felt that his appearance from day to day became worse which resulted in the decrease of P3's confidence in social interaction. P3 feels negative about others, which in turn makes P3 reluctant to interact with other people. He feels a burden to the family and has a fear of death. The quality of life as a social being is felt to be greatly reduced.

However, he had suffered CKD with hemodialysis for quite a long time, P3 is still often overwhelmed with negative feelings and thoughts. This makes the researcher feel that P3 is suitable for MBCT intervention.

The administration of MBCT interventions in all three study participants had the same effect. All three participants reported in their selftraining exercise report that the MBCT intervention helped participants to identify negative thoughts and feelings that attacked them. As long as negative thoughts and feelings come, the participants do mindfulness exercises to help them observe and become aware of their thoughts and feelings and slow down the response they will give. On the one hand, the slow response particularly makes participants able to improve their objective assessment abilities, so participants do not get absorbed in their negative thoughts and feelings. This evident happens because when the participant is aware of his or her thoughts and feelings, the participant also realizes that his or her thoughts and feelings are not a factual event that is taking place but in the form of thoughts and feelings that only exist in the participants' heads.

In the end, the three participants in this study stated that each of them was able to take time out to think even though it was overwhelmed by negative thoughts and feelings related to CKD with hemodialysis. This makes participants able to assess more objectively and respond to unpleasant situations more positively. This is what makes the quality of life of the participants improve. Participants can go through the day more positively, have fun, and find that even in a state of chronic pain participants can still live happily.

\section{Discussion}

Overall, the participants in this study experienced positive changes. Participants realized that during suffering from CKD with hemodialysis both in daily life or in the process of hemodialysis therapy they did not feel, realize, and enjoy the stages that were passed. During suffering from CKD with hemodialysis, participants assumed that all kinds of negative thoughts and feelings that were felt related to the condition of their illness were real. Hence, this makes participants as if waiting for negative thoughts and feelings come true. If it doesn't happen, what comes up is a feeling of relief because what is feared does not become real. But in the process, participants did not enjoy the moment in their path and were fixated on negative thoughts and feelings or in other words, participants were always overwhelmed with feelings of worry and not through their activities comfortably.

Starting from this prominence, participants in this study felt the need to play an active role when the intervention was given. The enthusiasm of participants to play an active role during the process of giving MBCT interventions made participants experience changes in life. These changes in the form of a way of assessing a disease that was originally considered a burden have now changed to assume that the illness experienced is a test from God. Seeing the disease makes them unable to do anything but rest now have changed 
to be able to localize the sickness and still be able to do simple activities.

Before being given an MBCT intervention, participants in this study often felt nervous when they were about to face the process of hemodialysis which now turned into being able to manage their anxiety so that they no longer felt restless when they were going to face the process of hemodialysis therapy.

The most beneficial thing from participating in the MBCT intervention for P1 is its readiness for hemodialysis. P1 always feels huge anxiety every time she will undergo hemodialysis therapy which is characterized by the appearance of a variety of emotions and affect the quality of sleep to the quality of life. But after following the MBCT intervention, P1 has another method to calm herself down while reducing her anxiety. That way, P1 can have quality sleep and be able to live the day better or in other words, P1 does not feel her quality of life is disrupted.

For P2 and P3, the MBCT intervention helped them to be able to regulate all kinds of negative thoughts and feelings. The MBCT intervention made P2 and P3 able to take breaks from all kinds of negative thoughts and feelings. The pause helps P2 and P3 to see their thoughts and feelings more objectively so that they are not easily dissolved. At P2, when it doesn't dissolve easily with his negative thoughts and feelings, he starts to become a little optimistic in undergoing treatment. In P3, not being easily dissolved by negative thoughts and feelings means making him grow self-confidence with his physical condition. The existence of positive changes in P2 and P3 is one proof that MBCT interventions have a positive effect on improving the quality of life in chronic kidney disease patients with hemodialysis.
Overall, the data obtained is illustrated that all participants experienced changes in aspects of quality of life both from aspects of generic core, the burden of kidney disease, symptoms and problems, and effects of kidney disease. This change occurred because of the MBCT intervention that was given helped the participants in this study to be in a mindfulness condition first before doing cognitive therapy. Segal et al. (2013) stated that in implementing MBCT the things that were targeted were concentration and awareness (being aware of thoughts, feelings, body impressions, and encouragement to react), meeting with sources of discomfort, thoughts, and feelings, receive, until release.

Based on the result of the analysis, it was found that the aspects of the generic core experienced an increase in scores after giving the MBCT intervention. The generic core aspect is an aspect that measures physical and mental functioning by including an assessment of general conditions, the ability to move, an assessment of social activities, and the anxiety felt due to CKD with hemodialysis experienced. Participants in this study generally stated that there was a change in the ability to move and change in looking at the condition of the disease being experienced.

In the participants in this study, there was a difference between P1 and P3 with P2, wherein P1 and P3 the increase in the generic core was the aspect with the second-largest increase in the score but in P2 the increase in score in the generic core aspect was in the last place. This is a unique finding from the generic core aspect where the difference that occurs between P1 and P3 with P2 is very large due to the long period of illness experienced. P1 and P3 have been CDK patients with hemodialysis in an annual period, 
P1 for four years and P3 for seven years, while P2 is relatively new at seven months.

Mayuda, Chasani, and Saktini (2017) stated that the long-term sufferer's long-term sufferers of CKD not a factor in the difference in the quality of life in patients with chronic kidney disease. But the result found in this study showed the opposite result, in which the duration of CDK disease with hemodialysis showed the process of adaptation that occurs to changes in the assessment of physical and mental functioning. This has caused the second-largest score increase in P1 and P3 to be in the generic core aspect, where P1 and P3 have carried out a long process of adaptation to changes in physical and mental conditions while the P2 adaptation process has only been running for seven months. The increase in scores occurred in P1 by 10 points and in P3 by 8 points, while in P2 the score increased by 3 points. Based on the difference in the significant increase in scores between $\mathrm{P} 1$ and P3 with P2, it can be concluded that in this study has a long enough to be researched of CKD disease with hemodialysis which plays an important role in increasing the quality of life scores significantly.

The burden of kidney disease aspect showed an improvement in the quality of life score after administration of an MBCT intervention. This aspect of burden of kidney disease has discussed how annoying CKD with hemodialysis is in daily life by measuring the time needed to complete activities, feelings of frustration that arise, or feelings of being a burden for families as CKD patients with hemodialysis. In this aspect, the changes that occur are CKD patients with hemodialysis, in general, feel a burden to their families both husband and parents. After giving the MBCT intervention, the changes that occur in general are attention, affection, time spent, and material support provided by the family is considered as motivation to continue to live their daily lives. Although the result of the qualitative analysis of the data found in the same, quantitative data descriptively showed differences. The difference is that in P1 and P3 the burden of kidney disease aspect is the aspect with the smallest score improvement, while in P2 this aspect increases the score to third. The increase in scores that occurred in $\mathrm{P} 1$ was 3 points and in $\mathrm{P} 3$ 4 points, while in $\mathrm{P} 2$ the score increase that occurred was 3 points.

The difference in score improvement in the aspect of burden of kidney disease is caused by the source of support that is obtained directly and continuously from the family and makes P1 and P3 feel that support is a burden. Especially in P1 the form of support provided made her feel uncomfortable for her husband because he spent money on treatment. In P3, the form of support he received from his parents made him feel useless as a child who should have been able to pay for and care for his own life but in reality, his parents were still financing and caring for him. The difference with P2 is that support does not obtain directly from the family, but P2 receives insight that his father's behavior is a form of affection with a different delivery after being given an MBCT intervention. Differences in the assessment of participants become a burden for the family which makes participants in this study have differences in increasing scores.

This research showed that family support is needed to make CKD patients with hemodialysis always excited, but in the improvement aspect of this family support also sometimes makes CKD patients with hemodialysis in this study feel a burden to their family. Bosniawan (2018) argued that social support is significantly influenced by the way individuals use social support itself, if the 
individual fails to internalize and internalize the social support he receives, the possibility of social support obtained will not mean to improve his quality of life. Based on this research, it can be concluded that the cause of the low score increase that occurs in the aspect of burden of kidney disease is due to family support that is always obtained so that appreciation appears not always positive but it is properly possible that feelings of discomfort and shame are also present, even though the quality of life in patients CKD in this study showed an increase.

The next aspect is aspects of symptoms and problems and aspects of the effects of kidney disease. Symptoms and problems aspects measure physical symptoms and problems that arise due to CKD with hemodialysis and aspects of the effect of kidney disease is stated about the effects of CKD with hemodialysis on daily life, both regarding food and fluid diets, inability to do activities such as usually, feeling dependent on others, and the emergence of anxiety and anxiety, as well as physical appearance that changes after undergoing hemodialysis. This aspect of symptoms of problems and the effect of kidney disease also showed increased scores after the administration of MBCT interventions. The participants stated that the mindful and aware condition made them able to feel the physical symptoms of CKD disease experienced and respond to the effects of physical symptoms or the effects of CKD disease more calmly and were not disturbed by thoughts and feelings present from CKD disease. Moreover, in determining the response that will be given to the stimulus effect of CKD with hemodialysis in daily life becomes more positive. Increasing of score that occurs in aspects of symptoms and problems are in P1 by 5 points, in P2 by 3 points, and in P3 by 7 points. Whereas in the aspect of the effect of kidney disease, the score improvement that occurred in
$\mathrm{P} 1$ was 11 points, in $\mathrm{P} 2$ it was 5 points, and in $\mathrm{P} 3$ it was 10 points. This showed that the provision of MBCT interventions can improve these aspects of quality of life. The difference in the score of the increase that occurs between P1 and P3 with P2, where $\mathrm{P} 2$ is the participant who has the smallest increase due to the process of adaptation to the disease experienced.

Based on the result of the analysis of aspects of quality of life, it was found that all aspects of quality of life have improved with the aspect of the effect of kidney disease showing the highest increase in all participants in this study as a result of giving MBCT interventions. P1 and P3 have a similarity in the increasing order of aspects, aspects of the effects of kidney disease, generic core aspects, aspects of symptoms and problems, and aspects of the burden of kidney disease. Whereas in P2 the sequence of scoring increases in each aspect starts from the aspect of the effect of kidney disease, aspects of symptoms and problems, aspects of the burden of kidney disease, and aspects of generic core. Increased scores per aspect on the quality of life scale and the changes obtained from the result of qualitative data analysis proved that the MBCT intervention has a positive effect on improving quality of life.

Even though it showed a positive effect on the quality of life of CKD patients after being given an MBCT intervention, the design and trial process in this study had limitations, including: 1) The implementation schedule of the MBCT intervention is excessively flexible, following the participant's physical condition in the study, if the participant's physical condition decreases, the MBCT intervention is delayed until the participant becomes healthier. This resulted in the discussion of homework being late so that not infrequently the participants had not been so 
detailed in telling the individual training session they did. 2) Research participants in this study are not homogeneous or do not have an equivalent period of illness. This makes the result of this study cannot be generalized its success in CKD patients based on time.

\section{Conclusion}

The conclusions of this study are: 1) Mindfulness-Based Cognitive Therapy (MBCT) interventions affect improving the quality of life for all participants. 2) The improvement in the quality of life occurred because the MBCT intervention helped to break the automatic thinking process that the participants had in this study, and with the help of the MBCT intervention the participants were able to feel, enjoy, observe, and reflect on their thoughts and feelings without rushing to respond. In other words, the MBCT intervention gives participants time to think, so that the reaction shown to a stimulus gets better. 3 ) Things that need to be considered in providing MBCT intervention is the convenience of participants to do mindfulness, especially when it relates to negative or unpleasant experiences from participants. If participants are not comfortable to observe and feel their negative experiences and feelings, the researcher is allowed to change into positive feelings to strengthen the participants themselves so that they are not dissolved by their negative thoughts or feelings.

\section{Suggestions}

For further researchers, it is recommended that they conduct support to the study participants so that they want to do individual exercises in sessions I, III, and IV routinely. So that participants can respond more positively to stimuli that are considered less enjoyable.

Providing psycho-education related to understanding mindful conditions, an overview of MBCT interventions, and things that will be done during the intervention should not be done only once and it should be explained in depth. This can help align the patient's initial condition with MBCT interventions. For further research methods, it is necessary to consider the use of two groups (experiment and control), which in this study cannot be done because patients who are willing to participate in the study are distinctively limite.[]

\section{References}

Aisara, S., Azmi, S., \& Yanni, M. (2018). Gambaran klinis penderita penyakit ginjal kronik menjalani yang hemodialisis di RSUP Dr. M. Djamil Padang. Jurnal Kesehatan Andalas, 7(1), 42-50.

Bakri, R. J., \& Usri, K. (2017). Gambaran quality of life pada pasien chronic kidney disease yang menjalani hemodialisis. In Prosiding Konfrensi Nasional III Psikologi Kesehatan. Jakarta: Fakultas Psikologi Universitas YARSI.

Bartley, T. (2012). Mindfulness-based cognitibe therapy for cancer. USA: John Wiley \& Sons.

Caninsti, R. (2013). Kecemasan dan depresi pada pasien gagal ginjal kronis yang menjalani terapi hemodialisis. Jurnal Psikologi Ulayat, 1(2), 207-222. https://doi.org/10.24854/jpu22013-22

Gooz, M. (2012). Chronic kidney disease. Croatia: Intech.

Hays, R. D., Kallich, J. D., Mapes, D. L., Coons, S. J., \& Carter, W. B. (1994). Development of the Kidney Disease Quality of Life (KDQOLTM) instrument. Quality of Life Research, 3(5), 329-338. https://doi.org/ 10.1007/BF00451725 
Hidayah, N. (2016). Studi deskriptif kualitas hidup pasien penyakit ginjal kronik yang menjalani hemodialisis di Rumah Sakit PKU Muhammadiyah Yogyakarta. Jurnal Keperawatan Muhammadiyah, 1(1), 50-57.

Indonesian Renal Registry. (2014). 7th Report of Indonesian Renal Registry. Retrieved from https://www.indonesianrenalregistry.org/data/INDONESIAN RENAL REGISTRY 2014.pdf

Jha, V., Garcia-Garcia, G., Iseki, K., Li, Z., Naicker, S., Plattner, B., ... Yang, C. W. (2013). Chronic kidney disease: Global dimension and perspectives. The Lancet, 382(9888), 260-272. https://doi.org/10.1016/S0140-6736(13)60687-X

Mayuda, A., Chasani, S., \& Saktini, F. (2017). Hubungan antara lama hemodialisa dengan kualitas hidup pasien penyakit gagal ginjal kronik (Studi di RSUP Dr. Kariadi Semarang). Jurnal Kedokteran Diponegoro, 6(2), 167-176.

Prodjosudjadi, W., Suhardjono, Suwitra, K., Pranawa, Widiana, I. G. R., Loekman, J. S., ... Working Group of the Indonesian Society of Nephrology. (2009). Detection and prevention of chronic kidney disease in Indonesia: initial community screening. Nephrology (Carlton, Vic.), 14(7), 669-674. https://doi.org/10.1111/j.1440-1797.2009.01137.x

Rawat, K. J., Joshi, K. S., \& Arora, R. D. (2017). Quality of life in patients on hemodialysis: A quasiexperiment with review of literature. International Journal of Medical Science and Public Health, 6(4), 786-791. https://doi.org/10.5455/ijmsph.2017.1061306122016

Reza, I. F. (2016). Implementasi coping religious dalam mengatasi gangguan fisik-psikis-sosial-spiritual pada pasien gagal ginjal kronik. Intizar, 22(2), 243-280. https://doi.org/ 10.19109/intizar.v22i2.940

Rustandi, H., Tranado, H., \& Pransasti, T. (2018). Faktor-faktor yang mempengaruhi kualitas hidup pasien chronic kidney disease yang menjalani hemodialisa di ruang hemodialisa. Jurnal Keperawatan Silampari, 1(2), 32-46. https://doi.org/10.31539/jks.v1i2.8

Sandra, Dewi, W. N., \& Dewi, Y. I. (2012). Gambaran stres pada pasien gagal ginjal terminal yang menjalani terapi hemodialisis di Rumah Sakit Umum Daerah Arifin Achmad Pekanbaru. Jurnal Ners Indonesia, 2(2).

Segal, Z. V., Williams, J. M. G., \& Teasdale, J. D. (2013). Mindfulness-based cognitive therapy for depression (2nd ed.). New York: Guilford Press.

Seidel, U. K., Gronewold, J., Volsek, M., Todica, O., Kribben, A., Bruck, H., \& Hermann, D. M. (2014). Physical, cognitive and emotional factors contributing to quality of life, functional health and participation in community dwelling in chronic kidney disease. PLOS ONE, 9(3), 315-332. https://doi.org/10.1371/journal.pone.0091176 